\title{
Methane turnover and temperature response of methane-oxidizing bacteria in permafrost-affected soils of northeast Siberia
}

\author{
Christian Knoblauch ${ }^{\mathrm{a}, *}$, Uta Zimmermann ${ }^{\mathrm{a}}$, Martin Blumenberg ${ }^{\mathrm{b}}$, \\ Walter Michaelis ${ }^{b}$, Eva-Maria Pfeiffer ${ }^{a}$ \\ a University of Hamburg, Department of Earth Sciences, Institute of Soil Science, Allende-Platz 2, 20146 Hamburg, Germany \\ ${ }^{\mathrm{b}}$ University of Hamburg, Department of Earth Sciences, Institute of Biogeochemistry and Marine Chemistry, Bundesstraße 55, 20146 Hamburg, Germany
}

\section{A R T I C L E I N F O}

\section{Article history:}

Received 1 May 2008

Received in revised form 8 July 2008

Accepted 17 August 2008

Available online 24 September 2008

\section{Keywords:}

Methane oxidation

Tundra soils

Microbial PLFA

Stable isotope probing

Permafrost

\begin{abstract}
A B S T R A C T
The abundance, activity, and temperature response of aerobic methane-oxidizing bacteria were studied in permafrost-affected tundra soils of northeast Siberia. The soils were characterized by both a high accumulation of organic matter at the surface and high methane concentrations in the water-saturated soils. The methane oxidation rates of up to $835 \mathrm{nmol} \mathrm{CH}_{4} \mathrm{~h}^{-1} \mathrm{~g}^{-1}$ in the surface soils were similar to the highest values reported so far for natural wetland soils worldwide. The temperature response of methane oxidation was measured during short incubations and revealed maximum rates between $22{ }^{\circ} \mathrm{C}$ and $28{ }^{\circ} \mathrm{C}$ The active methanotrophic community was characterized by its phospholipid fatty acid (PLFA)

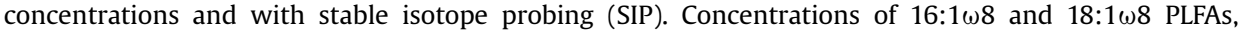
specific to methanotrophic bacteria, correlated significantly with the potential methane oxidation rates. In all soils, distinct 16:1 PLFAs were dominant, indicating a predominance of type I methanotrophs. However, long-term incubation of soil samples at $0{ }^{\circ} \mathrm{C}$ and $22^{\circ} \mathrm{C}$ demonstrated a shift in the composition of the active community with rising temperatures. At $0^{\circ} \mathrm{C}$, only the concentrations of 16:1 PLFAs increased and those of 18:1 PLFAs decreased, whereas the opposite was true at $22^{\circ} \mathrm{C}$. Similarly, SIP with ${ }^{13} \mathrm{CH}_{4}$ showed a temperature-dependent pattern. When the soils were incubated at $0{ }^{\circ} \mathrm{C}$, most of the incorporated label (83\%) was found in 16:1 PLFAs and only 2\% in 18:1 PLFAs. In soils incubated at $22{ }^{\circ} \mathrm{C}$, almost equal amounts of ${ }^{13} \mathrm{C}$ label were incorporated into 16:1 PLFAs and 18:1 PLFAs (33\% and 36\%, respectively). We concluded that the highly active methane-oxidizing community in cold permafrostaffected soils was dominated by type I methanotrophs under in situ conditions. However, rising temperatures, as predicted for the future, seem to increase the importance of type II methanotrophs, which may affect methane cycling in northern wetlands.
\end{abstract}

(c) 2008 Elsevier Ltd. All rights reserved.

\section{Introduction}

Wetlands are the major source of the climatically relevant trace gas methane, and their estimated contribution to global methane emissions is of $20-39 \%$ (Denman et al., 2007). Northern-latitude soils play a particular role in the global methane cycle because they contain one-third of the global organic carbon pool (Post et al., 1982). One-third of northern-latitude soils are underlain by permafrost (Zhang et al., 1999), and only a shallow surface layer (the active layer) thaws during the short summer period. Because water drainage is impeded by permafrost, water-saturated soils are widespread in northern lowlands. These soils are characterized by the accumulation of organic matter, anaerobic carbon turnover, and methane production. The effects of the observed and predicted

\footnotetext{
* Corresponding author. Tel.: +49 (0) 42838 2277; fax: +49 (0) 428382024. E-mail address: christian.knoblauch@uni-hamburg.de (C. Knoblauch).
}

climate changes will be stronger in the Arctic than the global average, and warming over the land in the Arctic north is expected to be twice as high as the global mean (Trenberth et al., 2007). As a result, increasing methane emissions from Arctic wetlands are expected (Wuebbles and Hayhoe, 2002). The most important sink for methane in wetland soils are aerobic methane-oxidizing bacteria, which use methane as their sole energy and carbon source. Depending on environmental conditions, methanotrophic bacteria may oxidize more than $90 \%$ of the methane produced before it reaches the atmosphere (Roslev and King, 1996; Popp et al., 2000). These microorganisms cluster taxonomically in the $\alpha$ Proteobacteria (type II) and the $\gamma$-Proteobacteria (type I). Methaneoxidizing bacteria can be identified in environmental samples by their specific unsaturated phospholipid fatty acids (PLFAs) (Bowman et al., 1991; Börjesson et al., 2004). These PLFAs are $16: 1 \omega 8$, which is synthesized almost exclusively by type I methanotrophs, and 18:1 $\omega 8$, which is specific to type II methanotrophs. Besides their two signature fatty acids, type I and type II 
methanotrophs also exhibit an overall different PLFA pattern, with 16:1 PLFAs predominating in type I and 18:1 PLFAs in type II (Bowman, 2006), with only a few exceptions among the acido-, thermo-, and halophilic methanotrophs (Heyer et al., 2005; Tsubota et al., 2005; Dedysh et al., 2007). The strong seasonality in the Arctic means that temperatures in the active layer may fluctuate between about $-30{ }^{\circ} \mathrm{C}$ in winter and $+10^{\circ} \mathrm{C}$ in summer (Boike et al., 2008). Our knowledge of how methanotrophs cope with these extreme temperatures is very limited. Which organisms are active at low in situ temperatures and how these communities will respond to the rising temperatures predicted for the future are unclear.

To improve our understanding of methane oxidation in cold permafrost-affected soils, we studied the abundance, activity, and temperature response of methane-oxidizing bacteria at two northeast Siberian tundra sites using activity measurements, PLFA distributions, and ${ }^{13} \mathrm{C}$ signatures of PLFAs. The methane-oxidizing community active at low in situ temperatures and its response to rising temperatures was also characterized using stable isotope probing of bacterial PLFAs (PLFA-SIP) with ${ }^{13} \mathrm{CH}_{4}$. This method allows the differentiation of active microbial communities and their responses to changing environmental conditions (Boschker et al., 1998; Blumenberg et al., 2005; Shrestha et al., 2008). The results presented give new insights into the adaptation of methanotrophic communities to low temperatures in Siberian permafrost-affected soils and their responses to predicted warming.

\section{Materials and methods}

\subsection{Investigation sites}

Two study sites in the coastal lowlands of the Siberian Laptev Sea were investigated. The area belongs to the zone of continuous permafrost, and has a trans-Arctic, continental climate. The soils at both sites are completely frozen for more than 8 months of the year. Only during the short summer season does a shallow surface layer thaw to a depth of less than $50 \mathrm{~cm}$. A mean annual air temperature of $-14.7^{\circ} \mathrm{C}$ and total summer precipitation of $72-208 \mathrm{~mm}$ (mean $137 \mathrm{~mm}$ ) were recorded between 1999 and 2005 on Samoylov Island, the second sampling site. The soil temperature at a depth of $9 \mathrm{~cm}$ ranged between $-34^{\circ} \mathrm{C}$ and $+10^{\circ} \mathrm{C}$ (Boike et al., 2008). The main study site was situated in a hilly plain rising $25-55 \mathrm{~m}$ above sea level in the Lena-Anabar lowland, close to Cape Mamontovy $\operatorname{Klyk}\left(73.60^{\circ} \mathrm{N}, 117.13^{\circ} \mathrm{E}\right)$. The plain is of late Pleistocene origin but is dissected by thermoerosional valleys, formed in the Holocene, with water-saturated soils at the bottom. Three soils were sampled in a transect through a thermoerosional valley, one on the upslope (VU), the second on the downslope (VD), and the third at the bottom of the valley (VB). The landscape on the second site on Samoylov $\left(72.22^{\circ} \mathrm{N}, 126.29^{\circ} \mathrm{E}\right)$, an island in the central part of the Lena River delta, is characterized by a microrelief of low-centred ice-wedge polygons (Fig. 1). Samples were collected from a soil profile in a polygon centre (PC). Further information on Samoylov Island has been given by Wagner et al. (2003).

\subsection{Soil sampling and analysis}

Soils at Mamontovy Klyk were sampled in August 2003, and at the PC on Samoylov in September 2003. For sampling, a pit was opened from the soil surface to the frozen permafrost table. Mixed samples were collected from the different soil horizons in sterile plastic bags. All collected samples were refrozen in the field in a letnik (cave in the frozen ground) and kept frozen until arrival in the laboratory. The refreezing of the samples was assumed to have only minor effects on the community composition and activity because the soil temperature drops below $-30^{\circ} \mathrm{C}$ every winter

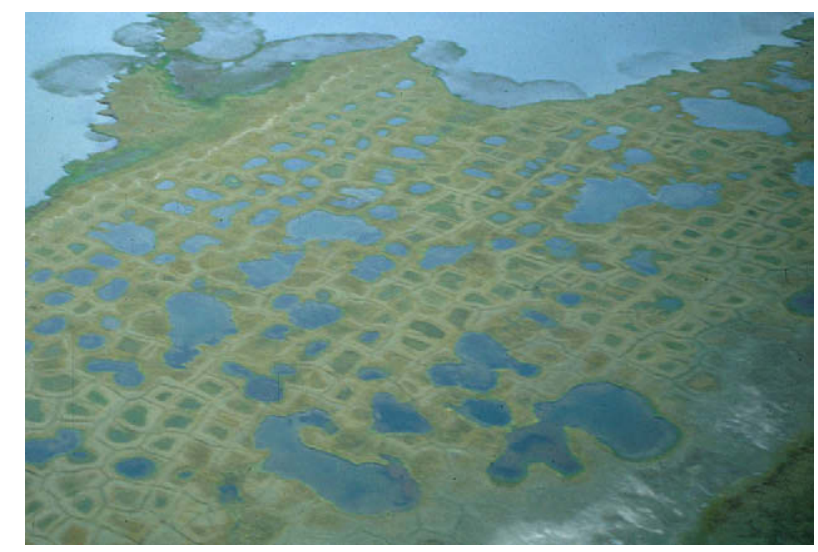

Fig. 1. Aerial view of the low-centred ice-wedge polygonal tundra in the Lena river delta, the characteristic landscape of Samoylov island.

under natural conditions. To evaluate the impact of refreezing, we measured ${ }^{13} \mathrm{CH}_{4}$ incorporation into the microbial PLFAs in the same sample in the field and in the laboratory after the sample had been stored frozen during transport (see Supplementary material). Total carbon and nitrogen were measured with an elemental analyser (VarioMAX Elementar Analysensysteme GmbH, Hanau, Germany) after the soil samples had been sieved $(<2 \mathrm{~mm})$, milled, and dried at $105{ }^{\circ} \mathrm{C}$. Soil $\mathrm{pH}$ was determined in a suspension of $10 \mathrm{~g}$ of fresh soil in $25 \mathrm{ml}$ of $0.01 \mathrm{M} \mathrm{CaCl}_{2}$ solution. Soil methane profiles were measured by transferring $40 \mathrm{~g}$ of fresh soil into a $130 \mathrm{ml}$ glass bottle containing $70 \mathrm{ml}$ of saturated $\mathrm{NaCl}$ solution. The bottle was immediately closed airtight and vigorously shaken. The methane concentration in the soil water was calculated from the methane concentration in the headspace, the headspace volume, and the water content of the sample. Methane was analysed using a gas chromatograph (GC-14B, Shimadzu Deutschland GmbH, Duisburg, Germany) equipped with a stainless steel Porapack-Q column and a flame ionization detector.

\subsection{Potential methane oxidation rates}

Potential methane oxidation rates $\left(V_{\mathrm{P}}\right)$ were measured in batch cultures. Fresh soil material ( $4 \mathrm{~g}$ ) was placed in flat-walled culture bottles $(50 \mathrm{ml})$ and distributed over the side wall as a thin layer. The bottles were sealed with rubber stoppers and incubated horizontally. The headspace contained $1 \%(\mathrm{v} / \mathrm{v})$ methane in air. Triplicate samples were incubated in the dark at $5{ }^{\circ} \mathrm{C}$ (depth profiles of methane oxidation rates). Quadruplicate samples were incubated at $0{ }^{\circ} \mathrm{C}, 6{ }^{\circ} \mathrm{C}, 10^{\circ} \mathrm{C}, 16^{\circ} \mathrm{C}, 22^{\circ} \mathrm{C}, 28^{\circ} \mathrm{C}, 32^{\circ} \mathrm{C}, 37^{\circ} \mathrm{C}$, and $42^{\circ} \mathrm{C}$ to determine temperature profiles of methane oxidation in the surface samples from VB $(0-14 \mathrm{~cm})$ and PC $(0-5 \mathrm{~cm})$. Methane was measured repeatedly and the oxidation rates were calculated from the initial linear reduction in methane using multiple data points. Heat-sterilised samples were used as the control. After at least half the methane had been consumed, the experiment was stopped and the dry weights of the samples were determined. Methane concentrations in the heat-sterilised controls did not change during the incubation.

\subsection{PLFA analysis}

Bacterial lipids were extracted from triplicate freeze-dried peat samples $(0.5 \mathrm{~g})$ using a modified Bligh and Dyer extraction procedure (White et al., 1979), and fractionated into neutral, glyco-, and phospholipids by silica gel column chromatography (MEGA BE-SI, Varian Deutschland GmbH, Darmstadt, Germany). The separated phospholipids were transmethylated to fatty acid methyl esters 
(FAMEs) by mild alkaline methanolysis, as described previously (Knief et al., 2003). The FAMEs were dissolved in hexane with 19:0 FAME (internal standard for quantification) and analysed by gas chromatography-mass spectroscopy (GC-MS; HP5890 Series II GCHP5971 MSD) with a $30 \mathrm{~m}$ capillary column $(0.25 \mathrm{~mm}$ inner diameter, film thickness $0.25 \mu \mathrm{m}$; HP5, Restek RTX-5MS). The double bond positions in monounsaturated FAMEs were determined by analysing their dimethyl disulfide adducts (Nichols et al., 1986).

\section{5. ${ }^{13} \mathrm{C}$ labelling of fatty acids}

To identify active members of the methane-oxidizing community at each study site, mixed samples from the soil layer with maximum methane-oxidizing activity were labelled with ${ }^{13} \mathrm{CH}_{4}$ (99At\% ${ }^{13} \mathrm{C}$; Chemotrade, Leipzig, Germany) in batch cultures either at the field station (PC) or in the laboratory in Germany (VU, VD and VB). Preliminary experiments revealed that the application of pure ${ }^{13} \mathrm{CH}_{4}$ did not affect the activity of the methanotrophs. Wet samples (4-12 g) were weighed into $50 \mathrm{ml}$ flat-walled culture bottles, which were sealed with rubber stoppers. ${ }^{13} \mathrm{C}$-labelled methane was added to a final concentration of $0.02 \%$ in the gas phase. Unlabelled $\mathrm{CO}_{2}$ was added to a final concentration of $5 \%$ in the headspace to minimize cross-feeding with ${ }^{13} \mathrm{CO}_{2}$ from methane oxidation. Samples were incubated in the dark at $0{ }^{\circ} \mathrm{C}$, unless otherwise stated. To test for the potential influence of incubation temperature on the labelling pattern, a surface sample $(0-5 \mathrm{~cm}$ depth) from the $\mathrm{PC}$ in Samoylov was labelled with ${ }^{13} \mathrm{C}$ methane at $0{ }^{\circ} \mathrm{C}$ and $28{ }^{\circ} \mathrm{C}$, as described above. After at least half of the added methane had been oxidized (1-7 days, depending on the incubation temperature), the experiment was stopped, and the PLFAs were isolated and quantified with GC-MS. Stable carbon isotope values for the lipids were analysed (two replicates) using a ThermoFinnigan Trace GC coupled to a Finnigan MAT 252 (Thermo Scientific, Dreieich, Germany) isotope ratio mass spectrometer (IRMS). The components were combusted to $\mathrm{CO}_{2}$ in a $\mathrm{CuO}-\mathrm{Ni}-\mathrm{Pt}$ furnace operated at $940{ }^{\circ} \mathrm{C}$. The standard deviations of the $\delta^{13} \mathrm{C}$ values for single compounds were usually less than $\pm 0.5 \%$. The isotopic compositions of the fatty acids were corrected for the addition of the carbon atom during the preparation of the methyl esters (Crossman et al., 2004). The amount of ${ }^{13} \mathrm{C}$ label incorporated into the different PLFAs was calculated using the PLFA concentration and the difference between the $\delta^{13} \mathrm{C}$ value for the labelled sample and that for the unlabelled control (Boschker and Middelburg, 2002). Finally, the fraction of label incorporated into each different fatty acid was calculated.

\subsection{Long-term incubations}

The growth of the methane-oxidizing communities at two different temperatures was studied in surface samples $(0-14 \mathrm{~cm}$ depth) from the active layer of the valley bottom (VB) at Mamontovy Klyk. Before the experiment, the temperature response of methane oxidation was measured and the PLFAs of the initially active methanotrophic community were labelled with ${ }^{13} \mathrm{CH}_{4}$ at $0{ }^{\circ} \mathrm{C}$, as described above. Three unlabelled samples $(4 \mathrm{~g}$ wet weight), processed in parallel, were incubated for 11 weeks at either $0{ }^{\circ} \mathrm{C}$ or $22{ }^{\circ} \mathrm{C}\left(T_{\text {opt }}\right)$ in $50 \mathrm{ml}$ glass bottles containing $5 \%$ methane $\left(\delta^{13} \mathrm{C}-55.8 \%\right.$ VPDB $)$ in air. The isotopic composition of the methane was determined with a Precon and a GC coupled to a Finnigan Delta Plus IRMS (Thermo Scientific, Dreieich, Germany). To prevent nutrient limitation during the incubation, one part of

Table 1

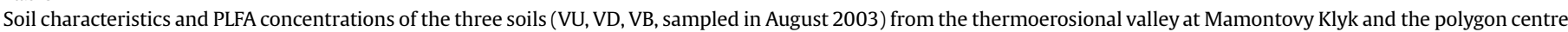
(PC, sampled in September 2003) on Samoylov

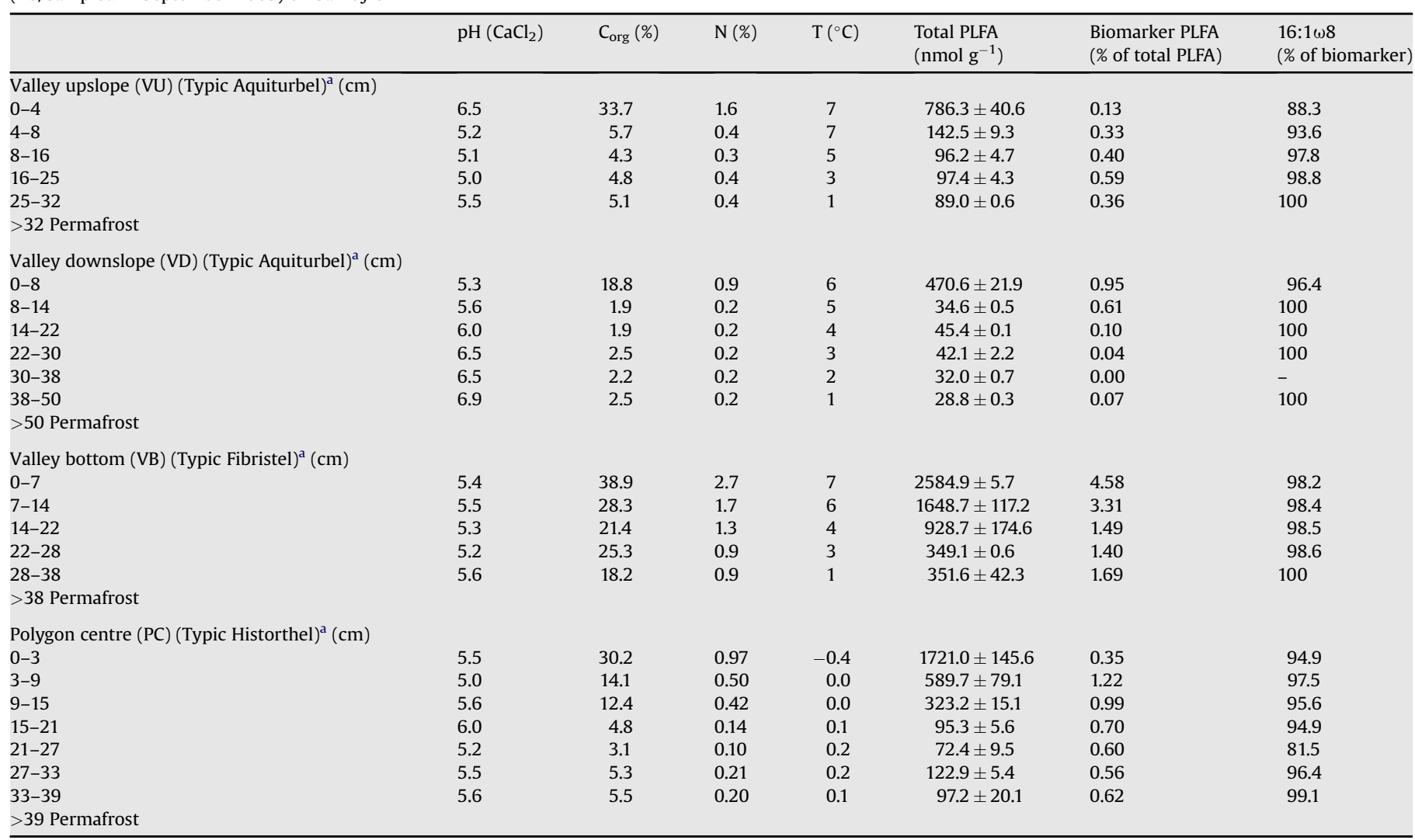

a Soil classification according to USDA (2006). 
NMS medium (Whittenbury et al., 1970) was added to four parts of fresh sample. The oxygen and methane consumed during the incubation period were repeatedly replaced. After 11 weeks, the headspace gas in the incubation bottles was replaced with ambient air and the active communities in two of the parallel cultures were labelled with ${ }^{13} \mathrm{CH}_{4}\left(99 \mathrm{At} \%{ }^{13} \mathrm{C}, 0.02 \% \mathrm{CH}_{4}\right.$ in air) for $24-72 \mathrm{~h}$ at the respective incubation temperature $\left(0^{\circ} \mathrm{C}\right.$ or $\left.22^{\circ} \mathrm{C}\right)$. The third parallel sample was incubated with unlabelled methane and used as the control. The PLFAs were then identified, quantified, and their stable isotopic composition measured, and the amount of label incorporated into the PLFAs calculated.

\section{Results}

\subsection{Characteristics of permafrost-affected soils}

The sites were characterized by permafrost below the uppermost $50 \mathrm{~cm}$ of the soil profile and an accumulation of organic carbon at the
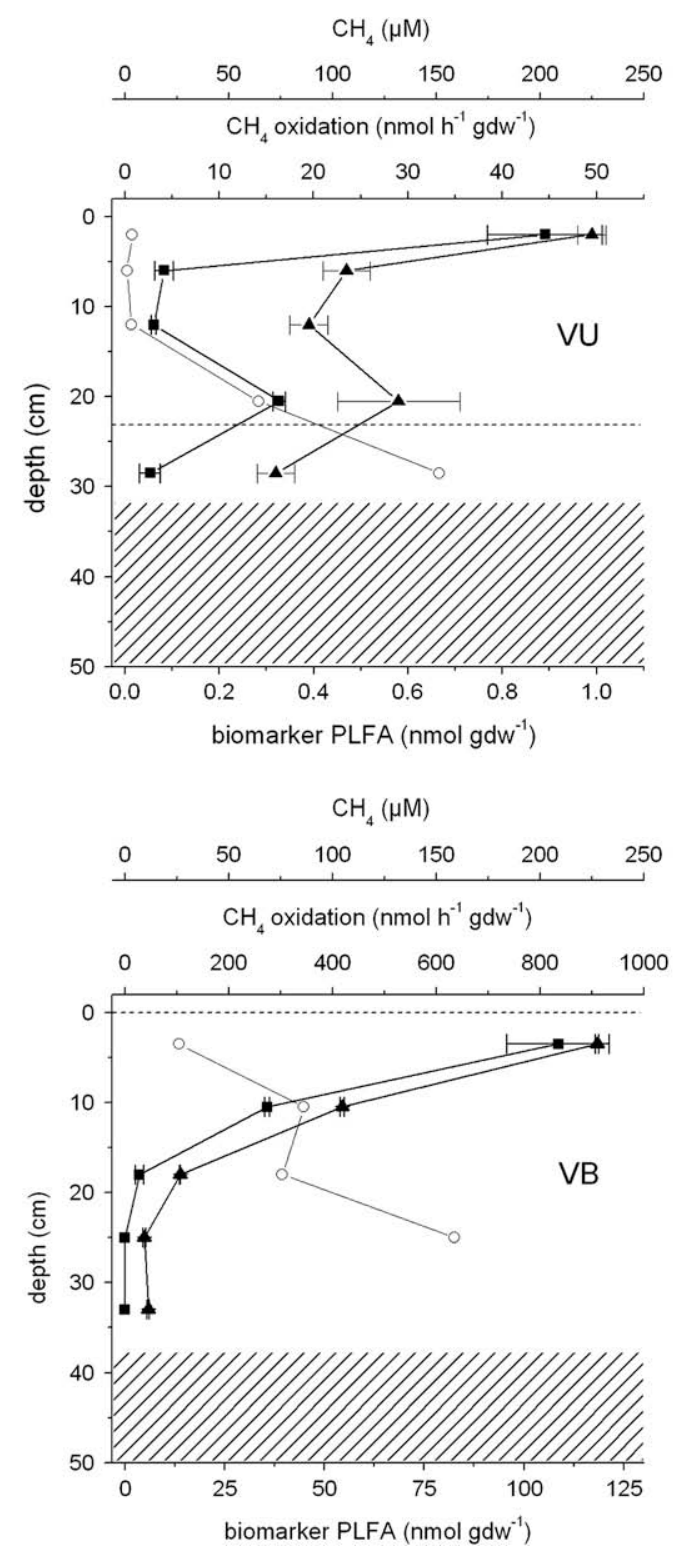

surface of 19-39\% (Table 1). The VU and VD soils at Mamontovy Klyk had a shallow peat horizon at the surface, underlain by mineral soil horizons with distinct cryoturbation. These two soils were classified as Typic Aquiturbels (USDA, 2006). The water table at VU was $23 \mathrm{~cm}$ below the surface during sampling and redoximorphic features were visible below the surface peat horizon, such as mottled iron oxides and manganese oxides. The vegetation was dominated by different mosses, sedges (Carex aquatilis), dryas (Dryas punctata), willows (Salix sp.), and various Poacea species. At VD, the water table was at the soil surface and the greyish-green mineral soil below the shallow peat horizon showed redox depletion and a relatively low content of organic carbon (1.9-2.5\%). Besides mosses, the common cotton grass (Eriophorum angustifolium) and the wide-leaf polargrass (Arctagrostis latifolia) dominated the vegetation. As at VD, the VB site at Mamontovy Klyk was water logged, but because the soil consisted of weakly decomposed organic material in the unfrozen active layer, it was classified as Typic Fibristel (USDA, 2006), with a vegetation dominated by mosses and sedges (C. aquatilis). The soil

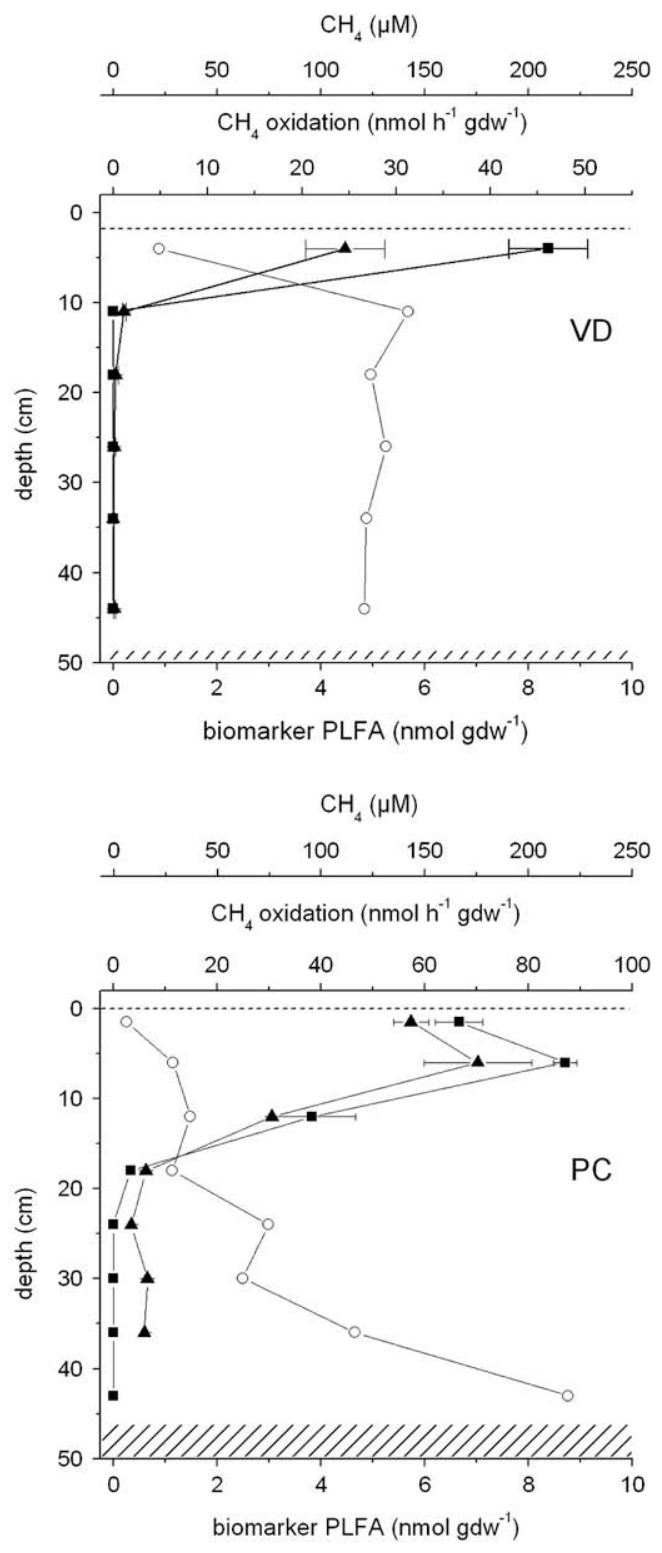

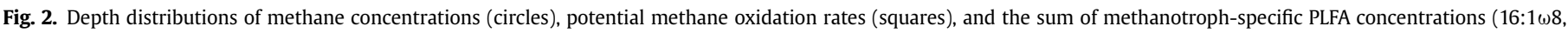

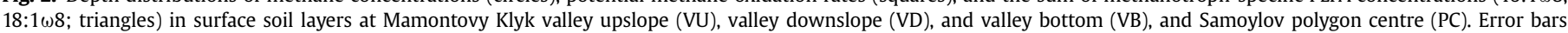

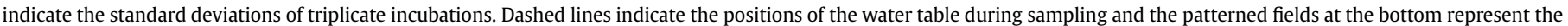
permanently frozen ground below the active layer. 
of the PC on Samoylov contained less organic carbon than that at VB in Mamontovy Klyk (Table 1), which is attributable to the repeated flooding of PC by the Lena River, resulting in the ongoing deposition of sandy sediments. The PC soil, classified as Typic Historthel (USDA, 2006), was covered by a typical wet moss-sedge tundra vegetation dominated by mosses and $C$. aquatilis. The water table was at the soil surface during sampling. The $\mathrm{pH}$ values were similar in all of the sampled soils and ranged between 5.0 and 6.9. Soil temperatures during sampling (Table 1 ) of the soils at Mamontovy Klyk in August 2003 decreased from about $7{ }^{\circ} \mathrm{C}$ at the surface to $1^{\circ} \mathrm{C}$ above the permanently frozen soil. The soil temperatures on Samoylov, measured in September 2003, were close to zero throughout the whole profile and the soil began to refreeze from the surface.

\subsection{Depth profiles of potential methane oxidation rates and methane concentrations}

Maximum potential methane oxidation rates $\left(V_{\mathrm{p}}\right)$ occurred close to the soil surface at all sampling sites (Fig. 2). The maximum $V_{\mathrm{p}}$ in the mineral soils ranged between $45 \mathrm{nmol} \mathrm{h}^{-1} \mathrm{~g}^{-1}$ at $\mathrm{VU}$ and $87 \mathrm{nmol} \mathrm{h}^{-1} \mathrm{~g}^{-1}$ at PC, but was almost 10 -fold higher in the organic soil at $\mathrm{VB}$, with values of $835 \mathrm{nmol} \mathrm{h}^{-1} \mathrm{~g}^{-1}$. In the water-saturated soils (VD, VB, and PC), $V_{\mathrm{p}}$ decreased rapidly with depth and no activity was observed $20 \mathrm{~cm}$ below the soil surface. Only at VU, where the water table was at a depth of $23 \mathrm{~cm}$ below the soil surface, a subsurface peak of $V_{\mathrm{p}}$ occurred directly above the water table and methane oxidation was measurable down to the permafrost table. Methane concentrations at VU decreased consistently from $152 \mu \mathrm{M}$ below the water table to $3 \mu \mathrm{M}$ at a depth of $12 \mathrm{~cm}$. At VD, methane concentrations were almost constant (121-142 $\mu \mathrm{M}$ ) throughout the water-saturated mineral horizons, where no methane oxidation was detectable, but decreased sharply in the surface organic horizon, consistent with a $V_{\mathrm{p}}$ of $46 \mathrm{nmol} \mathrm{CH}_{4} \mathrm{~h}^{-1} \mathrm{~g}^{-1}$.

\subsection{Microbial PLFAs}

The abundance of total microbial PLFAs decreased at all sites from the surface to the bottom of the active layer (Table 1) and correlated with soil organic carbon and total nitrogen (Spearman's rank correlation, $P<0.001$ ). The highest amounts of PLFAs were present in the surface horizon of VB $\left(2585 \mathrm{nmol} \mathrm{g}^{-1}\right)$ and lowest at VD $\left(471 \mathrm{nmol} \mathrm{g}^{-1}\right)$, where the PLFA abundance decreased by one order of magnitude between the surface peat horizon and the underlying mineral horizons. The biomarker PLFAs for methanotrophs (16:1 $1 \omega 8$ and $18: 1 \omega 8$, Table 1$)$ contributed up to $4.6 \%$ of the total PLFAs in the peat soil of VB and up to $1.2 \%$ in the organic-rich mineral soil of PC. At all sites, the abundance of the biomarker PLFAs for methanotrophs and potential methane oxidation rates showed the same depth distributions (Fig. 2). $V_{\mathrm{p}}$ correlated significantly with the concentrations of both biomarker PLFAs (Spearman's rank correlation, $P<0.001)$ but not with total PLFAs $(P>0.1)$. However, in the deeper, water-saturated horizons, where no
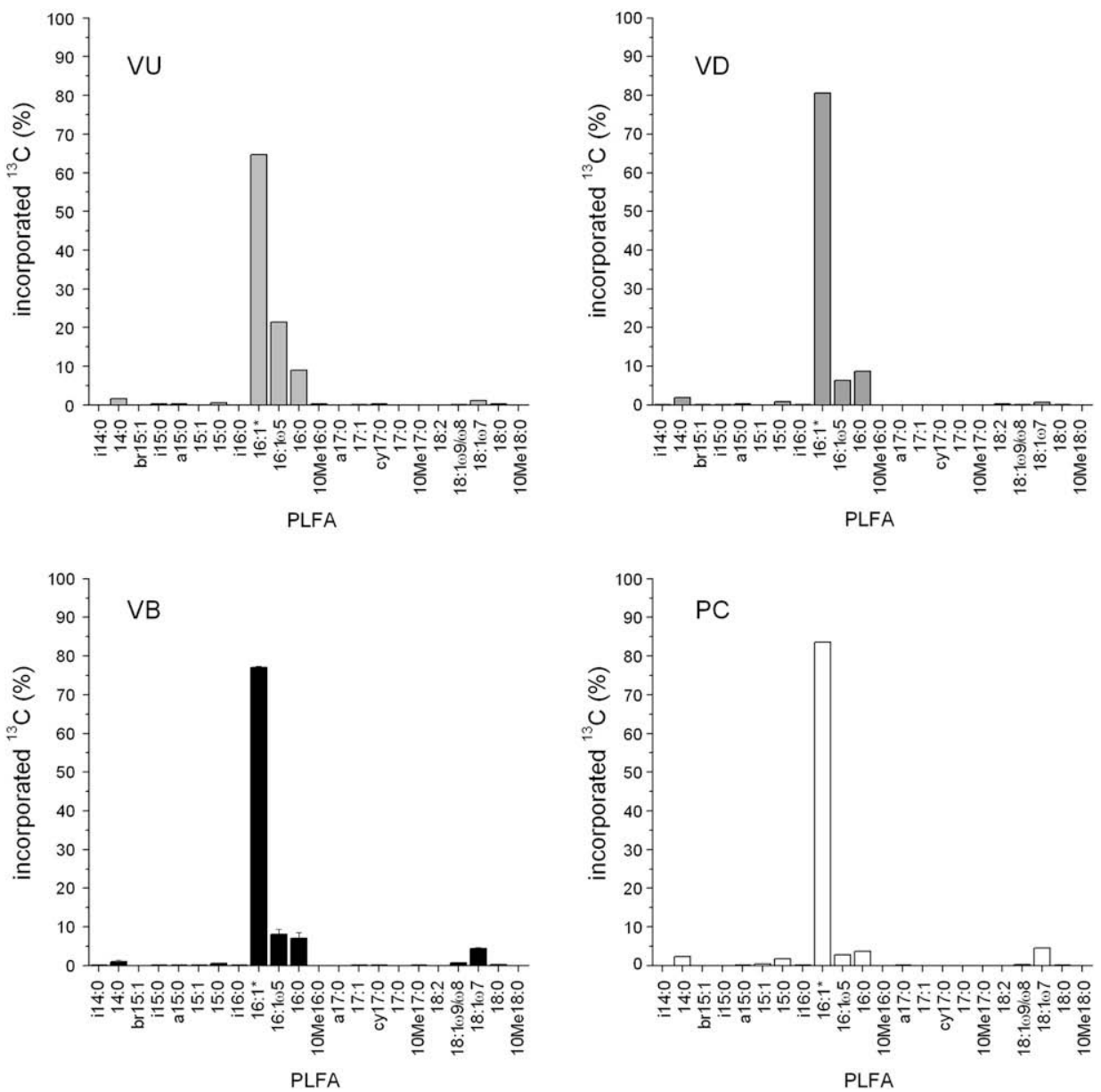

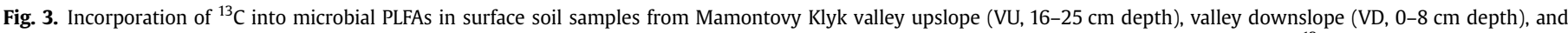

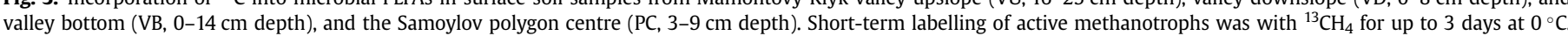

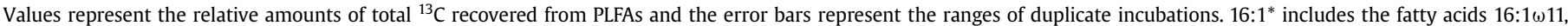

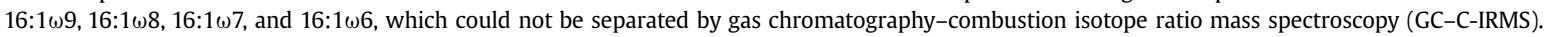



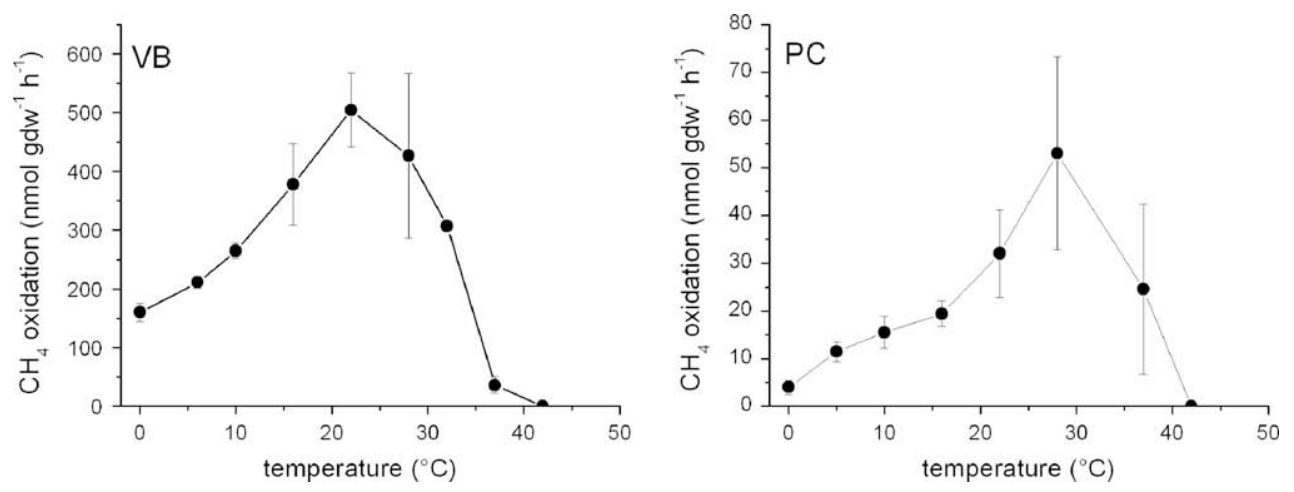

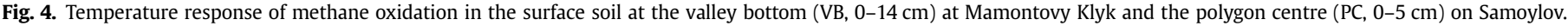
Error bars indicate the standard deviations of quadruplicate incubations.

potential methane oxidation was measurable, the biomarker concentrations remained at a constantly low level. As was the case for the methane oxidation rates, biomarker concentrations in the surface soils were much higher in the organic soil of VB $\left(118 \mathrm{nmol} \mathrm{g}^{-1}\right)$ than in the other mineral soils at Mamontovy Klyk or Samoylov (1-7 $\mathrm{nmol} \mathrm{g}^{-1}$ ). The methanotrophic communities at all sites were clearly dominated by bacteria containing the $16: 1 \omega 8$ biomarker, which comprised $88-100 \%$ (average $97 \%$ ) of the total

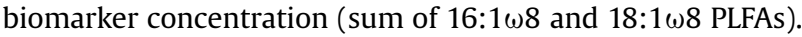

\subsection{Stable isotope probing of active methane oxidizers}

Labelling the methane-oxidizing bacteria with ${ }^{13} \mathrm{CH}_{4}$ in surface soil samples with maximum methane oxidation rates resulted in similar patterns at all sampling sites (Fig. 3). The peak containing the $16: 1 \omega 11,16: 1 \omega 9,16: 1 \omega 8,16: 1 \omega 7$, and 16:1 $1 \omega 6$ PLFAs contained between $66.6 \%(\mathrm{VU})$ and $83.5 \%(\mathrm{PC})$ of the total label incorporated into PLFAs. The second most important PLFA was 16:1 $\omega 5(2.8-21.4 \%$ of incorporated label), followed by the 16:0 PLFA (3.6-8.6\% of

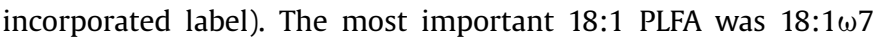
(0.7-4.6\% of incorporated label) and a mixed peak containing the

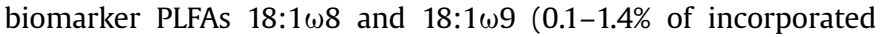
label). Freezing the samples during transport did not severely affect the labelling results because a similar labelling pattern was observed in a sample labelled in the field on Samoylov and the same sample after frozen transport (Supplementary Fig. 1).

\subsection{Temperature response of methane oxidation}

Despite a mean annual soil-surface temperature of $-10{ }^{\circ} \mathrm{C}$ (Boike et al., 2008), the maximum methane turnover was measured at $22{ }^{\circ} \mathrm{C}(\mathrm{VB})$ and at $28{ }^{\circ} \mathrm{C}(\mathrm{PC})$ (Fig. 4) in the surface soil samples with maximum methane oxidation rates. As well as the absolute temperature of the highest activity, the relative activity at $0{ }^{\circ} \mathrm{C}$ (the lowest temperature tested) was also considerably different at the two study sites. Whereas the surface soil of Mamontovy Klyk (VB) still retained $32 \%$ of its maximum activity at $0{ }^{\circ} \mathrm{C}$, only $8 \%$ of the maximum activity was measured in the Samoylov soil (PC).

\subsection{Growth of methane-oxidizing bacteria at different temperatures}

To assess the long-term effects of temperature on the growth of the methanotrophic community at VB, a surface sample $(0-14 \mathrm{~cm})$ was incubated for 11 weeks at $0^{\circ} \mathrm{C}$ or $22^{\circ} \mathrm{C}$ (temperature of maximum activity). The concentrations and stable carbon isotope ratios of the PLFAs were measured at the beginning and end of the experiment. Before incubation, 46 different fatty acids were detected, 44 of which could be identified (Table 2). The most
Table 2

Initial PLFA concentrations and $\delta^{13} \mathrm{C}$ values in the surface soil at VB and after 11 weeks incubation under $5 \%$ methane $(-55.8 \%$ VPDB $)$ at $0{ }^{\circ} \mathrm{C}$ or $22{ }^{\circ} \mathrm{C}$

\begin{tabular}{|c|c|c|c|c|c|c|}
\hline \multirow[t]{2}{*}{ PLFA } & \multicolumn{2}{|l|}{ Initial } & \multicolumn{2}{|l|}{$0^{\circ} \mathrm{C}$} & \multicolumn{2}{|l|}{$22{ }^{\circ} \mathrm{C}$} \\
\hline & $\begin{array}{l}\text { Conc. } \pm \text { SD } \\
\left(\mathrm{nmol} \mathrm{g}^{-1}\right) \\
(n=3)\end{array}$ & $\begin{array}{l}\delta^{13} \mathrm{C} \\
\text { (VPDB) }\end{array}$ & $\begin{array}{l}\text { Conc. } \pm \text { SD } \\
\left(\mathrm{nmol} \mathrm{g}^{-1}\right) \\
(n=3)\end{array}$ & $\begin{array}{l}\delta^{13} \mathrm{C} \\
\text { (VPDB) }\end{array}$ & $\begin{array}{l}\text { Conc. } \pm \text { SD } \\
\left(\mathrm{nmol} \mathrm{g}^{-1}\right) \\
(n=3)\end{array}$ & $\begin{array}{l}\delta^{13} \mathrm{C} \\
\text { (VPDB) }\end{array}$ \\
\hline $12: 0$ & $5.6 \pm 2.8$ & n.d. & $6.9 \pm 3.5$ & n.d. & $1.6 \pm 1.1$ & n.d. \\
\hline i13:0 & $2.0 \pm 0.9$ & n.d. & $1.2 \pm 0.3$ & n.d. & $1.4 \pm 0.6$ & n.d. \\
\hline a13:0 & $2.4 \pm 1.0$ & n.d. & $1.7 \pm 0.5$ & n.d. & $1.6 \pm 1.1$ & n.d. \\
\hline $13: 0$ & $2.7 \pm 0.8$ & n.d. & $2.0 \pm 0.5$ & n.d. & $\mathbf{0 . 8} \pm 0.5$ & n.d. \\
\hline i14:0 & $29.9 \pm 8.5$ & -37.8 & $20.1 \pm 3.5$ & -42.3 & $18.8 \pm 7.4$ & -43.8 \\
\hline $14: 0$ & $37.3 \pm 8.7$ & -40.4 & $34.7 \pm 5.9$ & -46.1 & $25.9 \pm 7.7$ & -40.8 \\
\hline br $15: 1$ & $18.9 \pm 3.5$ & -34.5 & $20.4 \pm 2.7$ & -41.6 & $15.8 \pm 8.3$ & -42.7 \\
\hline i15:0 & $81.3 \pm 15.1$ & -35.4 & $59.8 \pm 6.5$ & -36.7 & $72.8 \pm 19.4$ & -35.7 \\
\hline a15:0 & $93.1 \pm 20.6$ & -36.4 & $\mathbf{6 0 . 5} \pm 4.2$ & -37.2 & $\mathbf{5 8 . 9} \pm 13.1$ & -38.1 \\
\hline $15: 1$ & $7.7 \pm 1.7$ & -38.4 & $\mathbf{4 . 8} \pm 0.9$ & -38.9 & $2.3 \pm 0.1$ & -34.6 \\
\hline $15: 0$ & $26.2 \pm 4.3$ & -37.6 & $19.9 \pm 0.9$ & -41.5 & $12.3 \pm 2.5$ & -36.2 \\
\hline br $16: 0$ & $3.1 \pm 1.0$ & n.d. & $\mathbf{1 . 6} \pm 0.2$ & n.d. & $\mathbf{0 . 8} \pm 0.1$ & n.d. \\
\hline i16:1 & $14.0 \pm 3.3$ & -39.8 & $11.8 \pm 0.8$ & -36.6 & $\mathbf{4 . 9} \pm 1.1$ & n.d. \\
\hline i16:0 & $65.1 \pm 9.9$ & -37.1 & $46.8 \pm 1.7$ & -40.1 & $\mathbf{2 8 . 0} \pm 6.8$ & -39.8 \\
\hline $16: 1 \omega 11 c$ & $7.9 \pm 0.6$ & $-45.5^{1}$ & $11.5 \pm 2.2$ & $-53.4^{1}$ & $10.1 \pm 1.4$ & $-43.6^{1}$ \\
\hline $16: 1 \omega 9 c$ & $10.5 \pm 1.8$ & & $8.7 \pm 1.0$ & & $7.6 \pm 3.9$ & \\
\hline $16: 1 \omega 8 c$ & $36.0 \pm 4.6$ & & $\mathbf{8 8 . 6} \pm 15.4$ & & $\mathbf{1 5 . 9} \pm 2.8$ & \\
\hline $16: 1 \omega 7 c$ & $186.1 \pm 16.7$ & & $208.4 \pm 51.9$ & & $124.0 \pm 21.3$ & \\
\hline $16: 1 \omega 6 c$ & $13.4 \pm 2.3$ & & $19.3 \pm 2.7$ & & $3.4 \pm 0.7$ & \\
\hline $16: 1 \omega 7 t$ & $6.9 \pm 1.4$ & & $5.4 \pm 0.1$ & & $3.2 \pm 1.5$ & \\
\hline $16: 1 \omega 5 c$ & $27.7 \pm 4.7$ & $-51.8^{2}$ & $24.7 \pm 2.0$ & $-58.1^{2}$ & $40.8 \pm 9.0$ & $-39.8^{2}$ \\
\hline $16: 1 \omega 5 t$ & $22.5 \pm 3.0$ & & $\mathbf{5 0 . 3} \pm 6.5$ & & $8.7 \pm 1.8$ & \\
\hline $16: 0$ & $200.0 \pm 27.1$ & -37.6 & $151.3 \pm 14.7$ & -39.3 & $162.4 \pm 33.0$ & -37.2 \\
\hline i17:1 & $12.5 \pm 2.2$ & -33.1 & $10.6 \pm 0.8$ & -33.9 & $8.2 \pm 2.3$ & -35.1 \\
\hline 10Me16:0 & $33.6 \pm 2.1$ & -37.7 & $22.7 \pm 2.3$ & -39.7 & $18.9 \pm 1.4$ & -39.8 \\
\hline $\mathrm{i} 17: 0$ & $11.8 \pm 1.6$ & -33.3 & $9.9 \pm 1.5$ & -31.7 & $15.5 \pm 4.3$ & -31.7 \\
\hline a17:0 & $19.8 \pm 4.0$ & -34.2 & $13.6 \pm 0.6$ & -34.4 & $\mathbf{1 3 . 0} \pm 1.5$ & -35.1 \\
\hline $17: 1 \omega 8$ & $23.2 \pm 3.4$ & $-34.2^{3}$ & $14.3 \pm 1.4$ & $-34.4^{3}$ & $\mathbf{5 . 1} \pm 0.6$ & $-35.1^{3}$ \\
\hline $17: 1 \omega 6$ & $5.9 \pm 1.2$ & & $3.4 \pm 0.1$ & & $\mathbf{2 . 1} \pm 0.2$ & \\
\hline cy17:0 & $14.6 \pm 1.8$ & -36.0 & $20.2 \pm 3.6$ & -42.2 & $24.3 \pm 9.4$ & -40.0 \\
\hline $17: 0$ & $12.3 \pm 1.9$ & -36.0 & $\mathbf{9 . 4} \pm 0.6$ & -37.4 & $7.0 \pm 1.4$ & -39.5 \\
\hline 10Me17:0 & $23.0 \pm 1.7$ & -36.7 & $27.8 \pm 3.3$ & -36.9 & $17.1 \pm 4.0$ & -39.7 \\
\hline $18: 2$ & $43.7 \pm 10.7$ & -35.6 & $18.2 \pm 4.2$ & -35.9 & $\mathbf{2 4 . 0} \pm 4.6$ & -37.4 \\
\hline $18: 1 \omega 9 c$ & $126.7 \pm 21.2$ & $-35.9^{4}$ & $\mathbf{6 6 . 2} \pm 6.6$ & $-37.1^{4}$ & $35.8 \pm 7.4$ & $-36.2^{4}$ \\
\hline $18: 1 \omega 9 t$ & $1.4 \pm 1.0$ & & $1.9 \pm 0.5$ & & $1.5 \pm 0.1$ & \\
\hline $18: 1 \omega 8 c$ & $1.0 \pm 0.2$ & & $\mathbf{0 . 5} \pm 0.2$ & & $4.3 \pm 1.7$ & \\
\hline $18: 1 \omega 7 c$ & $95.4 \pm 12.0$ & $-34.7^{5}$ & $86.2 \pm 15.9$ & $-36.9^{5}$ & $\mathbf{1 8 8 . 8} \pm 16.3$ & $-40.0^{5}$ \\
\hline $18: 1 \omega 7 \mathrm{t}$ & $2.6 \pm 0.5$ & & $\mathbf{1 . 1} \pm 0.3$ & & $\mathbf{1 . 3} \pm 0.7$ & \\
\hline $18: 1 \omega 5 c$ & $2.3 \pm 0.5$ & n.d. & $1.2 \pm 0.2$ & n.d. & $2.9 \pm 1.6$ & n.d. \\
\hline 18:0 & $25.5 \pm 5.1$ & -36.5 & $17.2 \pm 1.0$ & -28.4 & $29.4 \pm 7.1$ & -32.9 \\
\hline 10Me18:0 & $64.2 \pm 4.9$ & -37.2 & $67.5 \pm 3.2$ & -37.3 & $19.6 \pm 5.0$ & -39.2 \\
\hline br19:0 & $5.5 \pm 1.2$ & n.d. & $\mathbf{4 . 4} \pm 0.3$ & n.d. & $\mathbf{2 . 8} \pm 0.3$ & n.d. \\
\hline cy19:0 & $11.2 \pm 1.6$ & n.d. & $8.2 \pm 0.5$ & n.d. & $12.0 \pm 3.1$ & n.d. \\
\hline 20:0 & $6.7 \pm 1.2$ & n.d. & $\mathbf{4 . 1} \pm 0.9$ & n.d. & $6.0 \pm 2.6$ & n.d. \\
\hline total & $1431.6 \pm 203.7$ & & $1279.7 \pm 111.0$ & & $1069.8 \pm 186.1$ & \\
\hline
\end{tabular}

${ }^{13} \mathrm{C}$ values with superscript number represent the results for a mixed peak of PLFAs that could not be separated by GC-C-IRMS. Mixed peaks are containing following PLFAs: ${ }^{1} 16: 1 \omega 11 \mathrm{c}, 16: 1 \omega 9 \mathrm{c}, 16: 1 \omega 8 \mathrm{c}, 16: 1 \omega 7 \mathrm{c}, 16: 1 \omega 6 \mathrm{c}$ and $16: 1 \omega 7 \mathrm{t} .{ }^{2} 16: 1 \omega 5 \mathrm{c}$ and

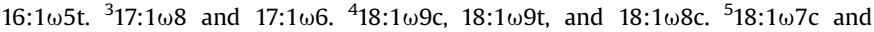
$18: 1 \omega 7 \mathrm{t}$. Standard deviations of the $\delta^{13} \mathrm{C}$ values were generally less than $0.5 \%$ VPDB. Values in bold indicate a significant difference relative to the initial PLFA concentration ( $U$ test, $\alpha=0.05$ ). 

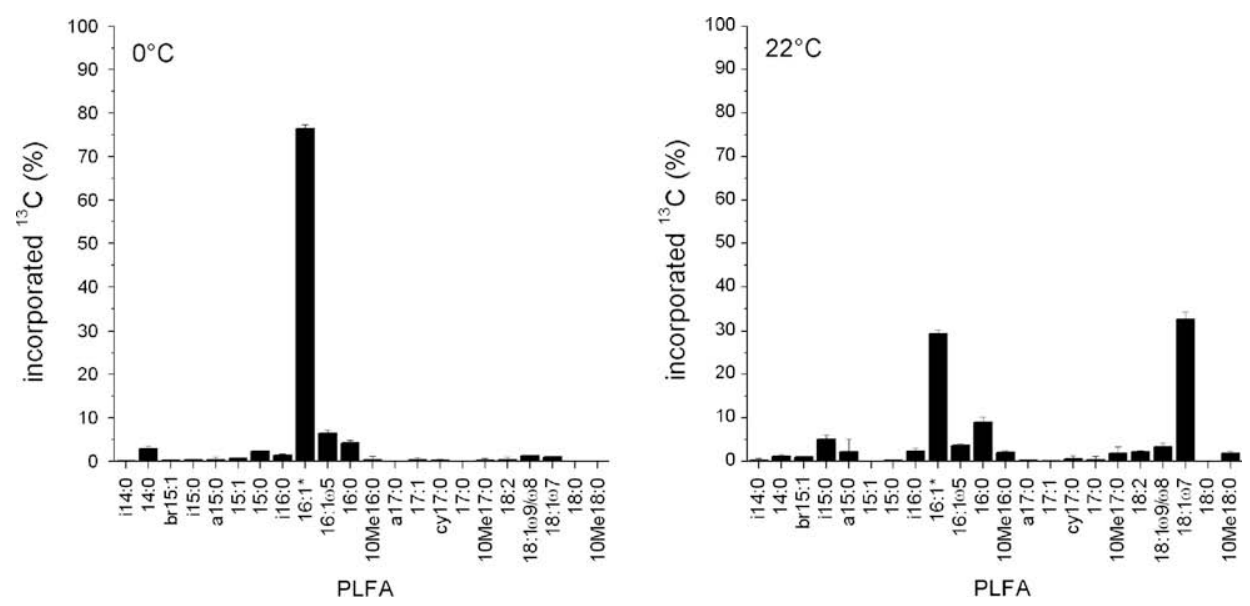

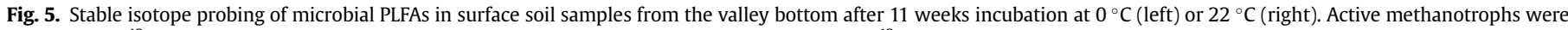

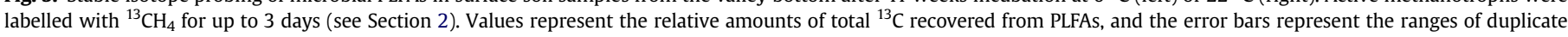
incubations. *16:1, see Fig. 3.

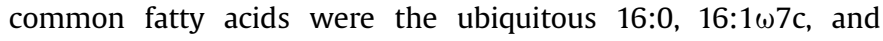

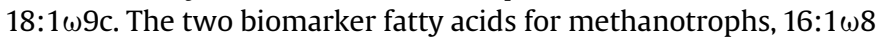
and $18: 1 \omega 8$, constituted up to $2.5 \%$ and $0.07 \%$ of all PLFAs, respectively. The stable carbon isotope ratios of the PLFAs ranged between $-33.1 \%$ and $-40.4 \%$ VPDB, except for the various 16:1 PLFAs ( $-45.5 \%$ to $-53.4 \%$ VPDB). After incubation for 11 weeks under an atmosphere of $5 \%$ unlabelled methane $\left(\delta^{13} \mathrm{C}=-55.8 \%\right.$ VPDB $)$ in air, the PLFA concentrations and $\delta^{13} \mathrm{C}$ values showed different patterns at $0{ }^{\circ} \mathrm{C}$ and $22^{\circ} \mathrm{C}$. At $0{ }^{\circ} \mathrm{C}$, the concentrations of several 16:1 PLFAs increased significantly and that of $16: 1 \omega 8$ more than doubled. Furthermore, the stable carbon isotope signatures of the 16:1 fatty acids decreased further. In contrast, the greatest reduction in PLFA concentrations was observed among the 18:1 fatty acids and the

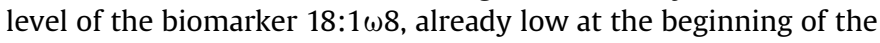
experiment, halved. The opposite response was observed at $22{ }^{\circ} \mathrm{C}$ in terms of PLFA concentrations and stable carbon isotope ratios.

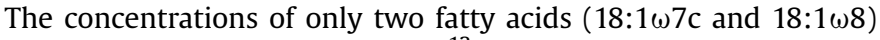

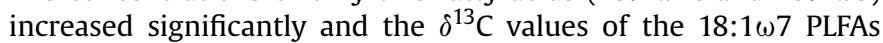
decreased from $-34.7 \%$ VPDB at the beginning of the experiment to $-40.0 \%$ VPDB after 11 weeks at $22{ }^{\circ} \mathrm{C}$. In contrast, the concen-

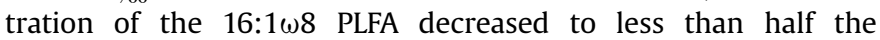
concentration in the initial sample, but was still almost four times more abundant than the 18:1 108 biomarker.

After the active methane-oxidizing community had been labelled with ${ }^{13} \mathrm{CH}_{4}$ at the beginning of the experiment (Fig. 3, bottom left), $85.1 \%$ of the recovered label was incorporated into the 16:1 PLFAs but only $2.5 \%$ into the $18: 1$ PLFAs. A similar result was observed after long-term incubation at $0{ }^{\circ} \mathrm{C}$. Stable isotope probing of PLFAs (Fig. 5, left panel) revealed $82.9 \%$ label incorporation into the $16: 1$ PLFAs and only $2.3 \%$ into the $18: 1$ PLFAs. However, after the same soil samples had been incubated for 11 weeks at $22{ }^{\circ} \mathrm{C}$, the results were considerably different (Fig. 5, right panel). Almost equal amounts of ${ }^{13} \mathrm{C}$ label were incorporated into the 16:1 PLFAs (33.0\% of incorporated label) and into the $18: 1$ PLFAs $(36.0 \%$ of incorporated label). The control samples showed that the incubation temperature during labelling had no significant effect on the PLFA labelling pattern (Supplementary Fig. 2).

\section{Discussion}

\subsection{Methane oxidation potentials}

The four permafrost sites at Mamontovy Klyk and Samoylov Island were similar in terms of soil $\mathrm{pH}$, temperature, and methane concentrations, but differed in the soil hydrological characteristics, soil organic matter accumulation, and microrelief. All sites showed anoxic carbon turnover, resulting in elevated methane concentrations at the bottom of the active layer. The surface horizons were composed of organic soil material but organic matter accumulation took place under permanently water-logged conditions at the valley downslope (VD) and valley bottom (VB) sites in Mamontovy Klyk and the polygon centre (PC) site on Samoylov. In the water-logged soils, the potential methane oxidation rates $\left(V_{\mathrm{p}}\right)$ showed similar profiles, with maximum rates at the surface and a steep decline in the uppermost $20 \mathrm{~cm}$ (Fig. 2). The maximum rates close to the water table are consistent with previous studies of peatlands (Moore and Dalva, 1997; Saarnio et al., 1997; Whalen and Reeburgh, 2000) and are most likely a result of overlapping gradients of $\mathrm{O}_{2}$ and $\mathrm{CH}_{4}$. However, at the valley upslope (VU) site, where the water table was $23 \mathrm{~cm}$ below the soil surface during sampling, maximum methane oxidation was observed at the soil surface, and only a smaller subsurface peak occurred above the actual water table (Fig. 2). Differences between the depth profiles of $V_{\mathrm{p}}$ at the unsaturated VU site and at the water-saturated sites VD, VB, and PC may be attributable to differences in soil hydrology. Only at VU were redoximorphic features detected, such as accumulations of iron and manganese oxides, indicating changing redox conditions in the soil profile, resulting from water table fluctuations during the year. During the snow thaw in spring, the soil is water saturated, with optimum conditions for methane oxidation closer to the soil surface. Water draining down the slopes of the thermoerosional valley later in the season leads to a drop in the water table and the optimum zone for methane oxidation. Hence, the $V_{\mathrm{p}}$ profiles measured in samples taken from VU 3 months after the surface soil had thawed reflect the average seasonal water table position rather than its actual position during sampling (Whalen and Reeburgh, 2000).

The maximum $V_{\mathrm{p}}$ measured at low temperatures $\left(5^{\circ} \mathrm{C}\right)$ in the studied tundra soils were unexpectedly high, indicating that methanotrophic bacteria contribute significantly to in situ carbon turnover. Whereas the maximum $V_{\mathrm{p}}\left(45-87 \mathrm{nmol} \mathrm{g}^{-1} \mathrm{~h}^{-1}\right)$ measured in the mineral soils (VU, VD, and PC) were at the higher end of those measured in cold environments at low temperatures (7-41 $\mathrm{nmol} \mathrm{g}^{-1} \mathrm{~h}^{-1}$ ) (Whalen and Reeburgh, 2000; Wagner et al., 2005), those at VB $\left(835 \mathrm{nmol} \mathrm{g}^{-1} \mathrm{~h}^{-1}\right)$ were almost 10 -fold higher and even in the higher range of those measured at or above $20^{\circ} \mathrm{C}$ in boreal and temperate peatlands (294-1417 $\mathrm{nmol} \mathrm{g}^{-1} \mathrm{~h}^{-1}$; Sundh et al., 1995b; McDonald et al., 1996; Saarnio et al., 1997). One reason for the high rates at VB might be the position of VB at the bottom of the thermoerosional valley, which probably results in an increased input of dissolved organic carbon (DOC) from the surface soils on 
the slopes of the valley. Also high plant productivity at VB, indicated by the high content of soil organic matter, might contribute to elevated fluxes of DOC into the soil. Increasing DOC input will support elevated methane production and hence supply substrate for the methane-oxidizing community in the surface soil at VB. Consistently, Ganzert et al. (2006) measured 4- to 7-fold higher methane production rates in the surface of a soil profile adjacent to $\mathrm{VB}$, relative to that at the PC site on Samoylov.

\subsection{Abundance of methanotrophs}

The potential methane oxidation rates $\left(V_{\mathrm{p}}\right)$ correlated highly significantly with the concentrations of the two biomarker PLFAs, $16: 1 \omega 8$ and $18: 1 \omega 8$, but not with total PLFA concentrations. The same correlation has also been reported for soils with high methane turnover (Sundh et al., 1995b; Börjesson et al., 2004) but not for upland soils without significant methane production or oxidation of atmospheric methane alone (Bull et al., 2000; Sundh et al., 2000). This indicates the relevance of these two biomarker PLFA for only those soils with elevated methane concentrations. At all four study sites, the contribution of biomarker PLFAs specific to aerobic methanotrophs to the total PLFAs (0.6-4.6\%; Table 1$)$ was highest close to the water table, where a peak of $V_{\mathrm{p}}$ was measured. Similar values $(1-4.1 \%$ of total PLFAs) have been reported for different methane-rich surface soils (Krumholz et al., 1995; Macalady et al., 2002). However, previous studies of the abundance of type I and type II methanotrophs in temperate and boreal wetlands, using either methanotroph-specific PLFAs (Krumholz et al., 1995; Sundh et al., 1995a; Henckel et al., 2000; Macalady et al., 2002; Shrestha et al., 2008) or 16S-RNA-specific oligonucleotide probes (Eller and Frenzel, 2001; Dedysh et al., 2003), showed similar population sizes for both types or a dominance of type II methanotrophs. In contrast, in the tundra soils we studied, the abundance and stable carbon isotope values for individual PLFAs (Tables 1 and 2) and the results of PLFA-SIP (Fig. 3) unambiguously demonstrate that 16:1 PLFAs, including 16:1 $\omega 8$, but not 18:1 PLFAs were almost exclusively associated with the activity of methaneoxidizing bacteria. First, $16: 1 \omega 8$ contributed between $82 \%$ and $100 \%$ (mean 97\%) of the total PLFA biomarker concentration for methanotrophs. Second, the stable carbon isotope signatures of $-46 \%$ to $-52 \%$ VPDB for the 16:1 PLFAs (Table 2) indicated the growth of methanotrophs containing $16: 1$ but not $18: 1$ fatty acids $(-35 \%$ VPDB) on the ${ }^{13} \mathrm{C}$-depleted methane in the permafrost $\left(\delta^{13} \mathrm{CH}_{4} \leq 70 \%\right.$ VPDB (Pfeiffer et al., 2007)). Third, between $85 \%$ and $87 \%$ of the ${ }^{13} \mathrm{C}$ label recovered after PLFA-SIP was incorporated into the 16:1 PLFAs, and only $0.8-5.2 \%$ into the $18: 1$ PLFAs (Fig. 3 ).

Before deducing the importance of type I and type II methanotrophs in the total methanotrophic community from the PLFA data, some limitations of the method must be considered. It has been shown that extremely acidic soils harbour type II methanotrophs, which predominantly produce the $18: 1$ fatty acids but also some 16:1 PLFAs (Dunfield et al., 2003; Dedysh et al., 2007). Therefore, this might affect the identification of type I and type II methanotrophs in acidic environments based on their PLFAs, especially if both 16:1 and 18:1 PLFAs are abundant. However, a significant abundance of these extraordinary methanotrophs in the communities of the tundra soils studied would have produced greater amounts of 18:1 PLFAs and higher ${ }^{13} \mathrm{C}$-label incorporation into 18:1 PLFAs than were observed, because 18:1 PLFAs are still the most abundant fatty acids in type II methanotrophs (Dunfield et al., 2003; Bowman, 2006; Dedysh et al., 2007). Hence, the clear dominance of the 16:1 PLFAs in all the tundra soils studied suggests a predominance of type I methanotrophs in the active methaneoxidizing communities in situ. Differences in the abundances of type I and type II methanotrophs have been related to different environmental parameters. In rice-based systems, it has been hypothesized that type I is more abundant under drained conditions, where methane concentrations are low, and type II under high methane and low oxygen conditions in flooded soil (Henckel et al., 2000; Macalady et al., 2002). Our results for permafrostaffected soils do not support this hypothesis because type I also prevailed at all water-logged sites with high methane and low oxygen concentrations. Temperature, which is certainly one of the decisive environmental parameters for microbial turnover in the tundra soils studied, also seems to be selective for these groups of methanotrophs, with a predominance of type I at low temperatures and type II at elevated temperatures (Börjesson et al., 2004; Gebert et al., 2004).

\subsection{Temperature response of methane oxidation}

Despite exhibiting high activity at low temperatures, the methanotrophic communities in the most active surface soils at VB and PC showed no psychrophilic temperature response (Fig. 4). Maximum oxidation rates were consistently measured between $22{ }^{\circ} \mathrm{C}$ (VB at Mamontovy Klyk) and $28^{\circ} \mathrm{C}$ (PC on Samoylov), which is far above the mean annual soil temperature of $-10^{\circ} \mathrm{C}$. However, the actual temperature range for methane oxidation in tundra soils is between about $0{ }^{\circ} \mathrm{C}$ and $10^{\circ} \mathrm{C}$, which is the temperature range of the unfrozen active layer in summer, when methane oxidation takes place. Studies of methane oxidation in different ecosystems between the subarctic and the tropics have indicated only a weak correlation between the temperature optimum $\left(T_{\mathrm{opt}}\right)$ for methane oxidation and environmental in situ temperatures. The $T_{\mathrm{opt}}$ for methane oxidation increases from about $20^{\circ} \mathrm{C}$ to $25^{\circ} \mathrm{C}$ in boreal bogs, and up to $36^{\circ} \mathrm{C}$ in subtropical paddy soil (Nesbit and Breitenbeck, 1992; Dunfield et al., 1993; Krumholz et al., 1995; Whalen and Reeburgh, 1996; Cai and Yan, 1999). The only indication of a low $T_{\text {opt }}$ for methane oxidation was reported by Liebner and Wagner (2006) in their study of methane oxidation in two permafrostaffected soils on Samoylov. The methane-oxidizing community in most parts of the soils they studied had temperature optima above $21^{\circ} \mathrm{C}$ or did not show a clear response to temperatures between $0{ }^{\circ} \mathrm{C}$ and $27^{\circ} \mathrm{C}$. Only close to the permafrost table, where the cell numbers of methanotrophs were lowest, did Liebner and Wagner (2006) find the highest methane oxidation rates at $4{ }^{\circ} \mathrm{C}$, and they assumed that a psychrophilic community of methane oxidizers had developed during the last several hundred years. We found no indication of a low $T_{\mathrm{opt}}$ for methane oxidation in either the two soils at VB and PC, or in the deep permafrost layers of Samoylov (Zimmermann, 2007). The reasons for these obvious differences might be found in both the properties of the sampling sites and the methodologies used. Liebner and Wagner (2006) studied two soils that were significantly different from those we studied in terms of their hydrology and soil organic matter. Furthermore, they used several incubation techniques to quantify methane oxidation that differed from those we applied. A similar temperature response to the one we observed for methane oxidation was reported by Ganzert et al. (2006) in a study of methanogenesis at PC and VB. They measured a strong and consistent increase in methane production rates after the incubation temperature was increased from $5{ }^{\circ} \mathrm{C}$ to $18{ }^{\circ} \mathrm{C}$ in all soil layers between the surface and the permafrost, and no indication of a psychrophilic methanogenic community. A conclusive picture of the temperature response of the microbial processes involved in the methane cycle of tundra environments requires more detailed studies.

To differentiate between the temperature response of microbial activity measured in short-term incubations (Fig. 4) and the effects of rising temperatures on the prolonged growth of methanotrophs, a long-term incubation experiment was conducted. At $0{ }^{\circ} \mathrm{C}$, the significant increase in only 16:1 PLFAs, the decline in 18:1 PLFA concentrations, and the reduction in the stable carbon isotope 
signatures for only the 16:1 PLFAs (Table 2) are consistent with the growth of type I methanotrophs on the ${ }^{13} \mathrm{C}$-depleted methane $\left(\delta^{13} \mathrm{C}=-55.8 \%\right.$ VPDB $)$ added as substrate. Furthermore, the almost complete incorporation of ${ }^{13} \mathrm{C}$ label into the $16: 1$ fatty acids (Fig. 5, left panel), as was the case before the long-term incubations (Fig. 3 bottom left), indicates that type I methanotrophs dominate the methane-oxidizing community growing at low in situ temperatures. A different picture emerged after the same soil samples were incubated at $22^{\circ} \mathrm{C}$. Increasing 18:1 PLFA concentrations, decreasing $\delta^{13} \mathrm{C}$ values for 18:1 PLFAs (Table 2), and almost equal incorporation of ${ }^{13} \mathrm{CH}_{4}$ into 18:1 and 16:1 fatty acids at the end of the experiment (Fig. 5, right panel) indicated the increasing importance of methanotrophs different from those that predominated at $0{ }^{\circ} \mathrm{C}$, most likely type II methanotrophs with dominantly 18:1 PLFAs. This observed shift in the composition of the active methanotrophic community can be attributed to the elevated temperature, because all other incubation conditions were identical at $0{ }^{\circ} \mathrm{C}$ and $22^{\circ} \mathrm{C}$. Interestingly, PLFA-SIP analysis indicated that the biomarker PLFA $18: 1 \omega 8$ was not the dominant fatty acid in the type II methanotrophs active at $22{ }^{\circ} \mathrm{C}$, but rather $18: 1 \omega 7$, because 10 times more ${ }^{13} \mathrm{C}$ was incorporated into $18: 1 \omega 7$ than into $18: 1 \omega 8$ at $22^{\circ} \mathrm{C}$ (Fig. 5 right panel). The predominance of the 18:1 $\omega 7$ PLFA has been reported for several Methylosinus, Methylocystis, Methylocella, and Methylocapsa strains, all type II methanotrophs (Bowman et al., 1991; Dedysh et al., 2002; Dunfield et al., 2003). Consequently, the contribution of methanotrophs to the total bacterial community might have been higher than deduced from the concentrations of the two fatty acids $16: 1 \omega 8$ and $18: 1 \omega 8$ alone.

Besides the increasing importance of 18:1 PLFAs at elevated temperatures, the decline in 16:1 fatty acid concentrations and the rise in their $\delta^{13} \mathrm{C}$ values imply that the growth of the organisms most active at low in situ temperatures was inhibited at $22^{\circ} \mathrm{C}$, the optimum temperature for methane turnover. There is evidence that type I methanotrophs are superior to type II strains at low temperatures. The growth of type I methanotrophs at low temperatures and of type II at elevated temperatures was reported for different landfill cover soils by Börjesson et al. (2004), who quantified methanotroph-specific PLFAs. Moreover, methanotrophs isolated at low temperatures $\left(\leq 10^{\circ} \mathrm{C}\right)$ belong to type I (Omelchenko et al., 1996; Bowman et al., 1997; Gebert et al., 2004). The PCR amplification of 16S rDNA and functional genes and the fluorescence in situ hybridization analysis of methanotrophs in northern taiga and tundra soils have indicated a predominance of type I methanotrophs (Kalyuzhnaya et al., 2002; Liebner and Wagner, 2006). This supports our observation of the predominance of these methanotrophs at low temperatures. If the methanotrophic bacteria in the tundra soils studied, which grow at low in situ temperatures, differ from those that grow at the temperature of maximum activity $\left(T_{\mathrm{opt}}=22^{\circ} \mathrm{C}\right)$, as suggested by our data, $T_{\mathrm{opt}}$ is not an appropriate parameter for describing the temperature adaptation of the methanotrophs active in situ.

Several studies, mainly of psychrophilic marine bacteria, have demonstrated that optimum growth temperatures can be significantly lower than those for respiration (Christian and Wiebe, 1974; Isaksen and Jørgensen, 1996; Knoblauch and Jørgensen, 1999). Hence, a temperature optimum for respiration that is far above the in situ temperature does not necessarily indicate that the community growing at the in situ temperature is not psychrophilic, as has been shown for marine sediments (Knoblauch et al., 1999; Sahm et al., 1999). In contrast to marine environments, most of the coldest terrestrial habitats, such as the tundra sites studied, undergo large temperature fluctuations during the year, from far below zero to above $15{ }^{\circ} \mathrm{C}$ at the soil surface in summer. Coldadapted microorganisms in the active layer of the tundra soils must cope with these fluctuations, including the elevated temperatures in summer. Therefore, more relevant than the absolute $T_{\mathrm{opt}}$ for methane oxidation in cold ecosystems is the relatively high turnover rate at low temperatures. Between $12 \%$ and $53 \%$ of maximum rates were measured at $5{ }^{\circ} \mathrm{C}$ in the studied tundra soils and in those from subarctic peatlands (Dunfield et al., 1993; Whalen and Reeburgh, 1996). In contrast, the soils of temperate and subtropical zones generally show negligible activity at or below $5{ }^{\circ} \mathrm{C}$ (Nesbit and Breitenbeck, 1992; Krumholz et al., 1995; Cai and Yan, 1999).

\section{Conclusions}

The methanotrophic communities studied in the northeast Siberian permafrost-affected soils are well adapted to low environmental temperatures, not by low-temperature optima for methane oxidation but by remarkably high methane oxidation rates at low temperatures. Stable isotope probing of microbial PLFAs indicated that the community active in situ is dominated by type I methanotrophs. Rising incubation temperatures resulted in the increasing importance of type II or still unknown type I methanotrophs. Furthermore, the growth of the methanotrophs responsible for the low-temperature activity was inhibited at elevated temperatures. Whether methane emissions are affected by the temperature-induced shift in the active community remains unclear. Hence, further studies of the temperature response of the microbial processes involved in the methane cycle will be necessary to establish the effects of rising temperatures on methane turnover in permafrost-affected soils.

\section{Acknowledgements}

We thank D. Wagner, W. Schneider, L. Kutzbach, and H. Meyer for their support during the field expeditions, and S. Kopelke and D. Mangels for their help with laboratory analyses. This study is part of the German-Russian project Process studies on permafrost dynamics in the Laptev Sea, financed by the German Ministry of Education and Research (BMBF). M. Blumenberg thanks the Deutsche Forschungsgemeinschaft for their financial support.

\section{Appendix. Supplementary data}

Supplementary data associated with this article can be found, in the online version, at doi:10.1016/j.soilbio.2008.08.020.

\section{References}

Blumenberg, M., Seifert, R., Nauhaus, K., Pape, T., Michaelis, W., 2005. In vitro study of lipid biosynthesis in an anaerobically methane-oxidizing microbial mat. Applied and Environmental Microbiology 71, 4345-4351.

Boike, J., Wille, C., Abnizova, A., 2008. Climatology and summer energy and water balance of polygonal tundra in the Lena River Delta, Siberia. Journal of Geophysical Research 113, G03025, doi:10.1029/2007JG000540.

Börjesson, G., Sundh, I., Svensson, B., 2004. Microbial oxidation of $\mathrm{CH}_{4}$ at different temperatures in landfill cover soil. FEMS Microbiology Ecology 48, 305-312.

Boschker, H.T.S., Middelburg, J.J., 2002. Stable isotopes and biomarkers in microbial ecology. FEMS Microbiology Ecology 40, 85-95.

Boschker, H.T.S., Nold, S.C., Wellsbury, P., Bos, D., de Graaf, W., Pel, R., Parkes, R.J. Cappenberg, T.E., 1998. Direct linking of microbial populations to specific biogeochemical processes by ${ }^{13} \mathrm{C}$-labelling of biomarkers. Nature 392, 801-805.

Bowman, J., 2006. The methanotrophs - the families Methylococcaceae and Methylocystaceae. In: Dworkin, M., Falkow, S., Rosenberg, E., Schleifer, K.-H., Stackebrandt, E. (Eds.), The Prokaryotes. Springer, New York, pp. 266-289.

Bowman, J.P., Skerratt, J.P., Nichols, P.D., Sly, L.I., 1991. Phospholipid fatty acid and lipopolysaccharide fatty acid signature lipids in methane-utilizing bacteria. FEMS Microbiology Ecology 85, 15-22.

Bowman, J.P., McCammon, S.A., Skerratt, J.H., 1997. Methylosphaera hansonii gen nov., sp. nov., a psychrophilic, group I methanotroph from Antarctic marinesalinity, meromictic lakes. Microbiology 143, 1451-1459.

Bull, I.D., Parekh, N.R., Hall, G.H., Ineson, P., Evershed, R.P., 2000. Detection and classification of atmospheric methane oxidizing bacteria in soil. Nature 405, 175-178.

Cai, Z., Yan, X., 1999. Kinetic model for methane oxidation by paddy soil as affected by temperature, moisture and N addition. Soil Biology \& Biochemistry 31, 715-725. 
Christian, R.R., Wiebe, W.J., 1974. The effects of temperature upon the reproduction and respiration of a marine obligate psychrophile. Canadian Journal of Microbiology 20, 1341-1345.

Crossman, Z.M., Abraham, F., Evershed, R.P., 2004. Stable isotope pulse-chasing and compound specific stable carbon isotope analysis of phospholipid fatty acids to assess methane oxidizing bacterial populations in landfill cover soils. Environmental Science and Technology 38, 1359-1367.

Dedysh, S.N., Khmelenina, V.N., Suzina, N., Trotsenko, Y.A., Semrau, J.D., Liesack, W. Tiedje, J.M., 2002. Methylocapsa acidiphila gen. nov., sp. nov., a novel methane-oxidizing and dinitrogen-fixing acidophilic bacterium from Sphagnum bog International Journal of Systematic and Evolutionary Microbiology 52, 251-261.

Dedysh, S.N., Dunfield, P.F., Derakshani, M., Stubner, S., Heyer, J., Liesack, W., 2003. Differential detection of type II methanotrophic bacteria in acidic peatlands using newly developed 16S rRNA-targeted fluorescent oligonucleotide probes. FEMS Microbiology Ecology 43, 299-308.

Dedysh, S.N., Belova, S.E., Bodelier, P.L.E., Smirnova, K.V., Khmelenina, V.N Chidthaisong, A., Trotsenko, Y.A., Liesack, W., Dunfield, P.F., 2007. Methylocystis heyeri sp. nov., a novel type II methanotrophic bacterium possessing 'signature' fatty acids of type I methanotrophs. International Journal of Systematic and Evolutionary Microbiology 57, 472-479.

Denman, K.L., Brasseur, G., Chidthaisong, A., Ciais, P., Cox, P.M., Dickinson, R.E., Hauglustaine, D., Heinze, C., Holland, E., Jacob, D., Lohmann, U. Ramachandran, S., Dias, P.L.d.S., Wofsy, S.C., Zhang, X., 2007. Couplings between changes in the climate system and biogeochemistry. In: Solomon, S., Qin, D. Manning, M., Chen, Z., Marquis, M., Averyt, K.B., Tignor, M., Miller, H.L. (Eds.), Climate Change 2007: The Physical Science Basis. Contribution of Working Group I to the Fourth Assessment Report of the Intergovernmental Panel on Climate Change. Cambridge University Press, Cambridge, United Kingdom/New York, NY, USA, pp. 499-588.

Dunfield, P., Knowles, R., Dumont, R., Moore, T.R., 1993. Methane production and consumption in temperate and subarctic peat soils: response to temperature and pH. Soil Biology \& Biochemistry 25, 321-326.

Dunfield, P.F., Khmelenina, V.N., Suzina, N.E., Trotsenko, Y.A., Dedysh, S.N., 2003. Methylocella silvestris sp. nov, a novel methanotroph isolated from an acidic forest cambisol. International Journal of Systematic and Evolutionary Microbiology 53, 1231-1239.

Eller, G., Frenzel, P., 2001. Changes in activity and community structure of methaneoxidizing bacteria over the growth period of rice. Applied and Environmental Microbiology 67, 2395-2403.

Ganzert, L., Jurgens, G., Münster, U., Wagner, D., 2006. Methanogenic communities in permafrost-affected soils of the Laptev Sea coast, Siberian Arctic, characterized by $16 \mathrm{~S}$ rRNA gene fingerprints. FEMS Microbiology Ecology.

Gebert, J., Groengroeft, A., Schloter, M., Gattinger, A., 2004. Community structure in a methanotroph biofilter as revealed by phospholipid fatty acid analysis. FEMS Microbiology Letters 240, 61-68.

Henckel, T., Roslev, P., Conrad, R., 2000. Effects of $\mathrm{O}_{2}$ and $\mathrm{CH}_{4}$ on presence and activity of the indigenous methanotrophic community in rice field soil. Environmental Microbiology 2, 666-679.

Heyer, J., Berger, U., Hardt, M., Dunfield, P.F., 2005. Methylohalobius crimeensis gen. nov., sp. nov., a moderately halophilic, methanotrophic bacterium isolated from hypersaline lakes of Crimea. International Journal of Systematic and Evolutionary Microbiology 55, 1817-1826.

Isaksen, M.F., Jørgensen, B.B., 1996. Adaptation of psychrophilic and psychrotrophic sulfate-reducing bacteria to permanently cold marine environments. Applied and Environmental Microbiology 62, 408-414.

Kalyuzhnaya, M.G., Makutina, V.A., Rusakova, T.G., Nikitin, D.V., Khmelenina, V.N., Dmitriev, V.V., Trotsenko, Y.A., 2002. Methanotrophic communities in the soils of the Russian northern taiga and subarctic tundra. Microbiology 71 227-233.

Knief, C., Altendorf, K., Lipski, A., 2003. Linking autotrophic activity in environmental samples with specific bacterial taxa by detection of ${ }^{13} \mathrm{C}$-labelled fatty acids. Environmental Microbiology 5, 1155-1167.

Knoblauch, C., Jørgensen, B.B., 1999. Effect of temperature on sulfate reduction, growth rate, and growth yield in five psychrophilic sulfate-reducing bacteria from Arctic sediments. Environmental Microbiology 1, 457-467.

Knoblauch, C., Sahm, K., Jørgensen, B.B., 1999. Psychrophilic sulfate-reducing bacteria isolated from permanently cold Arctic marine sediments: description of Desulfofrigus oceanense gen. nov., sp. nov., Desulfofrigus fragile sp. nov. Desulfofaba gelida gen. nov., sp. nov., Desulfotalea psychrophila gen. nov., sp. nov., and Desulfotalea arctica, sp. nov. International Journal of Systematic Bacteriology 49, 1631-1643.

Krumholz, L.R., Hollenback, J.L., Roskes, S.J., Ringelberg, D.B., 1995. Methanogenesis and methanotrophy within Sphagnum peatland. FEMS Microbiology Ecology 18, 215-224

Liebner, S., Wagner, D., 2006. Abundance, distribution and potential activity of methane oxidising bacteria in permafrost soils from the Lena Delta, Siberia. Environmental Microbiology 9, 107-117.

Macalady, J.L., McMillan, A.M.S., Dickens, A.F., Tyler, S.C., Scow, K.M., 2002. Population dynamics of type I and II methanotrophic bacteria in rice soils. Environmental Microbiology 4, 148-157.

McDonald, I.R., Hall, G.H., Pickup, R.W., Murrell, J.C., 1996. Methane oxidation potential and preliminary analysis of methanotrophs in blanket bog peat using molecular ecology techniques. FEMS Microbiology Ecology 21, 197211.

Moore, T.R., Dalva, M., 1997. Methane and carbon dioxide exchange potentials of peat soils in aerobic and anaerobic laboratory incubations. Soil Biology \& Biochemistry 29, 1157-1164.

Nesbit, S.P., Breitenbeck, G.A., 1992. A laboratory study of factors influencing methane uptake by soils. Agriculture Ecosystems and Environment 41, 39-54. Nichols, P.D., Guckert, J.B., White, D.C., 1986. Determination of monounsaturated fatty acid double-bound position and geometry for microbial monocultures and complex consortia by capillary GC-MS of their dimethyl disulfide adducts. Journal of Microbiological Methods 5, 49-55.

Omelchenko, M.V., Vasileva, L.V., Zavarzin, G.A., Saveleva, N.D., Lysenko, A.M., Mityushina, L.L., Khmelenina, V.N., Trotsenko, Y.A., 1996. A novel psychrophilic methanotroph of the genus Methylobacter. Mikrobiologiya 65, 384-389.

Pfeiffer, E.-M., Knoblauch, C., Stoof, G., Wagner, D., Meyer, H., 2007. Isotopic studies on the ${ }^{13} \mathrm{C}$-fractionation during $\mathrm{CH}_{4}$-production in polygonal and thermokarst lakes of the Lena Delta. Reports on Polar and Marine Research 550, 72-75.

Popp, T.J., Chanton, J.P., Whiting, G.J., Grant, N., 2000. Evaluation of methane oxidation in the rhizosphere of a Carex dominated fen in north central Alberta, Canada. Biogeochemistry 51, 259-281.

Post, W.M., Emanuel, W.R., Zinke, P.J., Stangenberger, A.G., 1982. Soil carbon pools and world life zones. Nature 298, 156-159.

Roslev, P., King, G.M., 1996. Regulation of methane oxidation in a freshwater wetland by water table changes and anoxia. FEMS Microbiology Ecology 19 105-115

Saarnio, S., Alm, J., Silvola, J., Lohila, A., Nykänen, H., Martikainen, P.J., 1997. Seasonal variation in $\mathrm{CH}_{4}$ emissions and production and oxidation potentials at microsites on an oligotrophic pine fen. Oecologia 110, 414-422.

Sahm, K., Knoblauch, C., Amann, R.I., 1999. Phylogenetic affiliation and quantification of psychrophilic sulfate-reducing isolates in marine Arctic sediments. Applied and Environmental Microbiology 65, 3976-3981.

Shrestha, M., Abraham, W.-R., Shrestha, P.M., Noll, M., Conrad, R., 2008. Activity and composition of methanotrophic bacterial communities in planted rice soil studied by flux measurements, analyses of pmoA gene and stable isotope probing of phospholipid fatty acids. Environmental Microbiology 10, 400-412.

Sundh, I., Borgå, P., Nilsson, M., Svensson, B.H., 1995a. Estimation of cell numbers of methanotrophic bacteria in boreal peatlands based on analysis of specific phospholipid fatty acids. FEMS Microbiology Ecology 18, 103-112.

Sundh, I., Mikkela, C., Nilsson, M., Svensson, B.H., 1995b. Potential aerobic methane oxidation in a Sphagnum-dominated peatland-controlling factors and relation to methane emission. Soil Biology \& Biochemistry 27, 829-837.

Sundh, I., Börjesson, G., Tunlid, A., 2000. Methane oxidation and phospholipid fatty acid composition in a podzolic soil profile. Soil Biology \& Biochemistry 32, $1025-1028$.

Trenberth, K.E., Jones, P.D., Ambenje, P., Bojariu, R., Easterling, D., Tank, A.K., Parker, D., Rahimzadeh, F., Renwick, J.A., Rusticucci, M., Soden, B., Zhai, P., 2007. Observations: surface and atmospheric climate change. In: Solomon, S., Qin, D., Manning, M., Chen, Z., Marquis, M., Averyt, K.B., Tignor, M., Miller, H.L. (Eds.), Climate Change 2007: The Physical Science Basis. Contribution of Working Group I to the Fourth Assessment Report of the Intergovernmental Panel on Climate Change. Cambridge University Press, Cambridge, United Kingdom/New York, NY, USA, pp. 235-336.

Tsubota, J., Eshinimaev, B.T., Khmelenina, V.N., Trotsenko, Y.A., 2005. Methylothermus thermalis gen. nov., sp. nov., a novel moderately thermophilic obligate methanotroph from a hot spring in Japan. International Journal of Systematic and Evolutionary Microbiology 55, 1877-1884.

USDA, 2006. Keys to Soil Taxonomy. United States Department of Agriculture, Soil Survey Staff.

Wagner, D., Kobabe, S., Pfeiffer, E.-M., Hubberten, H.-W., 2003. Microbial controls on methane fluxes from a polygonal tundra of the Lena Delta, Siberia. Permafrost and Periglacial Processes 14, 173-185.

Wagner, D., Lipski, A., Embacher, A., Gattinger, A., 2005. Methane fluxes in permafrost habitats of the Lena Delta: effects of microbial community structure and organic matter quality. Environmental Microbiology 7, 1582-1592.

Whalen, S.C., Reeburgh, W.S., 1996. Moisture and temperature sensitivity of $\mathrm{CH}_{4}$ oxidation in boreal soils. Soil Biology \& Biochemistry 28, 1271-1281.

Whalen, S.C., Reeburgh, W.S., 2000. Methane oxidation, production, and emission at contrasting sites in a boreal bog. Geomicrobiology Journal 17, 237-251.

White, D.C., Davis, W.M., Nickels, J.S., King, J.D., Bobbie, R.J., 1979. Determination of the sedimentary microbial biomass by extractable lipid phosphate. Oecologia 40, 51-62.

Whittenbury, R., Phillips, K.C., Wilkinson, J.F., 1970. Enrichment, isolation and some properties of methane-utilizing bacteria. Journal of General Microbiology 61, 205-218.

Wuebbles, D.J., Hayhoe, K., 2002. Atmospheric methane and global change. EarthScience Reviews 57, 177-210.

Zhang, T., Barry, R.G., Knowles, K., Hegnibottom, J.A., Brown, J., 1999. Statistics and characteristics of permafrost and ground-ice distribution in the Northern Hemisphere. Polar Geography 2, 132-154.

Zimmermann, U., 2007. Methane Oxidising Bacterial Communities in Soils and Sediments of the Siberian Permafrost. PhD thesis, University of Hamburg, Department of Earth Sciences, Hamburg, 123 pp. (in German). 